\title{
DOĞU VE BATI ARASINDA İSLAM
}

Aliya İzzetbegoviç (2015). Doğu ve Batı Arasında İslam, çev. Salih Şaban, Klasik Yayınları, İstanbul, 361 s. ISBN: 9758738229

Maşite SEVIML $\dot{I}^{1}$

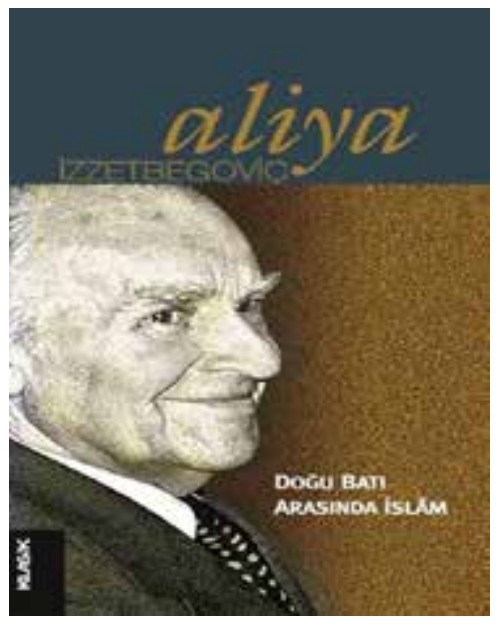

Aliya İzzetbegoviç, 1925 yılında Bosna Hersek'in Bosanski Samac kasabasında dünyaya geldi. O, Müslümanları Avrupa'ya dışarıdan girmiş kimseler olarak gören bir çevrede yetişti. Saraybosna'da bir Alman Lisesi'nde eğitim gördü. Lise döneminde arkadaşları ile birlikte " Müslüman Gençler Kulübü" nü kurdu. Bu kulübe üye olmas1 gerekçesiyle 1946 yılında üç yıl hapse mahkûm edildi. İlerleyen yıllarda entelektüel çalışmalarla meşgul oldu. İslam Deklarasyonu'nu yayınladi. 1983 yılında düşüncelerinden dolayı tekrar hapse mahkûm edildi. 5 yıl hapis hayatından sonra Yugoslavya'nın dağılma sürecine girdiği dönemde Demokratik Eylem Partisi'ni kurdu ve bu partini genel başkanı seçildi. Komünist yönetimin çökmesiyle birlikte yapılan ilk serbest seçimlerde Bosna Hersek Federal Cumhuriyeti Devlet Başkanı oldu. Sirp ve Hırvat güçlere karşı yürütülen bağımsızlık savaşına liderlik yaptıktan sonra 1995'te savaşa son veren Dayton Anlaşması'nı imzaladı. 1996 yılında yapılan seçimlerde üçlü başkanlık konseyine seçildi. 2000 yılında sağlık nedenlerini gerekçe göstererek başkanlık görevinden istifa eden İzzetbegoviç 19 Ekim 2003'te vefat etti. İzzetbegoviç entelektüel, eylem adamı, siyasetçi, özgürlük savaşçısı ve düşünür kimliği ile halkına öncülük etmiş bir isimdir. $O$, bu özellikleriyle İslam dünyasında yeni bir lider tipinin öncüsü sayılmaktadır(s. 5 ).

Aliya İzzetebegoviç’in Doğu ve Batı Arasında İslam adlı eseri, "Bat1 Düşüncesinin Temelleri " ve " İslam iki Kutuplu Birlik" adlı iki bölümden

\footnotetext{
${ }^{1}$ Hitit Üniversitesi İlahiyat Fakültesi Lisans Öğrencisi, e-posta: matisesevimlii@gmail.com
} 
oluşur. İlk kısımda bütün dinlerin özünde var olan temel ilkeler ve Batı dünyasının düşünce yapısı anlatılır. İkinci bölümde ise İslam dininin içinde bulunduğu düalizmden ve onun diğer dinlerle karşılaştırılmasından bahsedilir.

Kitabın giriş bölümünde yazar, modern dünyada var olan ideolojik çatışmada İslam'ın yeri nerededir sorusuna cevap arar. Bu noktada o, dünya görüşlerini dini, materyalist ve İslami olmak üzere üç grupta toplar. Birinci görüşe göre yegâne varlık ruh, ikincisine göre madde, üçüncü görüşe göre ise ruh ve maddenin birliğidir, ki bu İslam'dır. Eserde tartışılan mesele, ikili bir hayat yaşanıp yaşanamayacağı değil, bunu isteyerek ve anlayarak yaşayıp yaşayamayacağımızdır. İzzetbegoviç'e göre ise İslam'ın esas özelliği onun sahip olduğu düalizmdir. İslam bu yönüyle bugün modern çağın içinde bulunduğu paradokslara bir çıkış kapısı mahiyetindedir(s.13-15).

Yazar, İslam'ın günümüz dünyasında yeri ve konumunu tespit ettikten sonra Batı Düşüncesi'nin temellerini açıklamak üzere tekâmül ve yaratma, kültüruygarlık, sanat fenomeni, ahlak vb. konulardan bahseder ve insanın nereden geldiği konusunu, tekâmül ve yaratma kavramları çerçevesinde inceler. Ona göre, insanın kökenine ait düşünceler her yerde farklılık arz eder. Bilim, bunu zoolojiye, sanat ve din ise yaratılmışlığa dayandırır; yani asıl konu insanın yaratılışla mı yoksa evrimsel bir süreçle mi meydana geldiği sorusudur (s. 3334). Materyalistlerin görüşüne göre insan "mükemmel hayvan" olarak tanımlanır. Onlar her zaman görünen, zahir dünyayı dikkate alırlar; dolayısıyla ruhun inkârı söz konusudur. Fakat dinde bu durum tam tersidir. Ruhu yok sayarak insanı açıklamak imkânsızdır. Çünkü sanatkârların eserleri, daima sanatkârının ruhunun izlerini taşır. Yazara göre, Rafael'in resimlerini eliyle değil ruhuyla yapması, Bethowen'ın en kıymetli eserlerini tamamen sağır olduğu bir dönemde icra etmesi bunu en iyi açıklayan örneklerdir. Ayrıca, en iptidai insanın hayvanlarda olduğu gibi yaşamları avc1lık sayesinde idi. Fakat insan avdan önce yaptığı dua, kurban ve büyü, gibi pek çok faaliyetle o dönemde bile farkını ortaya koymuştu. Bu da gösteriyor ki ruhun varlığını inkâr ederek insanı açıklamak imkânsızdır. İzzetbegoviç, verdiği örneklerden hareketle insan ve hayvan arasındaki kesin farkın manevi, ahlaki ve dini bir tavırda olduğunu ifade eder (s. 38-48).

İzzetbegoviç insanın ilk ortaya çıkışıyla kültür ve uygarlık arasındaki ilişki üzerinde durmaya gayret eder. Çünkü ona göre meydana gelme, ilk alet ve kültürle ilişki içindedir. Alet kavramı, insan onu keşfetmeden önce de vardı; 
dolayısıyla yazara göre bu durum, her zaman açıklanabilir bir kavram olmuştur. Fakat insanın alete bir mana yükleyerek ruhunun yansıması sayılan ilk resmi yapması, onu diğerlerinden ayıran bir noktanın başlangıcıdır. Bu faaliyet kültür ve sanatın ilk yansımasıdır. Böylelikle insan nerede zuhur ettiyse onunla beraber din ve sanat da zuhur etmiştir(s. 85-90). İnsanın tabiatla mücadelesi ve ona hükmetme çabası uygarlığın başlangıcıdır. Okul ve eğitim ise bu çabaya en fazla destek veren yapılardır. Fakat burada kastedilen eğitimin tenkitçi düşünce yeteneğine dayanması gerekir. Bugün dünyada $\mathrm{SSCB}$ ve $\mathrm{ABD}$ en uygar devletler sayılabilirler; fakat en kültürlü ülkeler değildirler. İşte bu noktada kültür, öznesinin insan, gayesinin terbiye ile insanın kendi kendine hakim olması yönüyle uygarlıktan ayrılır (s. 90-97). Yazarın burada varmak istediği sonuç şu şekilde ifade edilebilir: Uygarlıktan en uzak ilkel toplumların ve iptidai insanın, bugünün gelişmiş teknolojiye sahip uygar sayılan insan toplulukları karşısında gösterdikleri fevkalade yaşama gücü ve sahip oldukları ahlak, modern dünyanın başarısızlığından başka bir şey değildir.

Aliya İzzetbegoviç, kültürden uzak bir uygarlığı başarısızlık olarak değerlendirdiği için insanın dünyayı anlama çabasını ve İslam'ın modern dünyadaki yerini sanat, ahlak ve tarih kavramları etrafında inceler. Ona göre, sanat maddeden ziyade insan şahsiyeti ile uğraşır. Dolayısıyla bir sanat eseri daima sanatkârının şahsiyetine bağlıdır. Bu yönüyle o orijinaldir. İlim ise durağan olanı inceler ve var olanı keşfetmeye yöneliktir. Örneğin; lisan ilmi insanların kendini ifade etmesinde bir yerde yetersiz kalmış ve onlar bunun sonucunda dans, resim ve şiir gibi pek çok ifade şekilleri geliştirmişlerdir. Buradan hareketle İzzetbegoviç sanatın, insanın kendini açıklama çabasının en üst seviyesi olarak tanımlar ve sanatın din ile de sıkı bir ilişkisi olduğunun altını çizer. Bu tespitine ise, geçmiş dönemlere ait kiliselerin aynı zamanda bir sanat galerisi olması ya da müzik alanında ortaya koyulan eserlerin dini muhtevalı olmalarını bunun önemli örnekleri olarak aktarır. Sanat, ahlak ve tarih ile ilgili ortaya koyduğu bu tespitlerinden sonra İzzetbegoviç şu sonuca varır: Geçmiş dönemde sanat kendini çok fazla ifade etme imkânı buldu ve bunun neticesinde sayısız edebiyatçı, şair ve sanatkâr yetişti. Fakat baskıcı rejimlerin, ihtilallerin hüküm sürdüğü bir dünyada fizikçi, devlet adamı ve siyasetçiden başka hiçbir şey yetişmedi. Bu durum mimariye de yansıdı ve bugünün insanı ruhu olmayan binalarda ve kültürün yok olduğu şehirlerde kendilerini yaşamaya mahkûm ettiler (s. 125-140). 
Ayrıca yazar din, ahlak ve siyasetin özünün "saf insaniyet"e dayandığını söyler. Menfaat gözetmeyen bir hareket, insandaki mevcut manevi değerlerle bir anlam kazanır ve ahlaklı faaliyete döner, yani ahlaklı faaliyeti ortaya koyan, sonuç değil kişinin iç dünyasındaki kararıdır. Sanatta da bu durum aynıdır; eserin yokluğu, sanatın olmadığı anlamına gelmez. Aliya İzzetbegoviç’in bahsettiği ahlak tasavvuruna göre, bu dünyada mağlup olan ve neticesiz kalan faaliyetlerin, bizde ahlak kavramına karşılık gelmesinin sebebi başka bir dünyanın varlığına inanmamızdandır. Onun şu sözleri konuyu açıklar niteliktedir: 'Rahatını, hürriyetini ve hatta hayatını kaybeden bir kimse nasıl galip olabilir? Bu dünyada olmasa gerek. Dolayısıyla bu ancak yaşadığımız dünyadan her hususta bambaşka bir dünyada olabilir. Bütün peygamber ve vaizlerden daha fazla bunlardır öbür dünyanın habercileri" (s. 162). Böyle bir ahlak tasavvurunda sonuç değil, niyet elbette daha önemlidir. Çünkü " insan, yaptığı değil her şeyden önce istediği, meylettiği şeydir’' (s.166).

Ahlak ve dinde vazife tüm zorluklara rağmen yerine getirilir ve ikisi de bu dünya ile sınırlı değildir. Ona göre, ahlak ve din müşterektir ve bedenden uzak manevi bir ortamda yaşam bulabilirler. Ayrıca yazar, ateist insanlarda ahlaka uygun davranışların görülmesini, ateizmin ahlakla ilişkisini ve bu toplumların ahlak tasavvurlarının yaratıcı ile bağdaştırılıp bağdaştırılamayacağını da açıklar. İzzetbegoviç, ateist görüşe sahip bir kişinin sergilediği ahlaki hareketlerin, onun çocuklukta kazandığı bir terbiyenin ürünü olduğu ifade eder ve bu durumun hayatının her safhasında kendini dışa vurduğu belirtir. Fakat ona göre 'ahlaklı ateizm' ifadesi bir topluma işaret eder ve bu yönden o, kesinlikle dini bir temele dayanır. Çünkü geçmişte din dışı bir toplum mevcut değildir. $\mathrm{Bu}$ da gösteriyor ki toplumların sahip olduğu değerler geçmişten günümüze kadar gelen dini kimlikli kültürel öğelerdir. İzzetbegviç 'Güneşin çoktan battığı yerde gecenin bütün sıcaklığı yine güneştendir" (s.195). diyerek söz konusu tespitlerini farklı bir tasvir içerisinde aktarmaya gayret eder. Burada yazarın vurgulamak istediği nokta, din olmadan ahlak olmaz, tatbikatta ise ahlakl1lık mümkündür ve ateizm üzerine bir ahlak disiplinin kurulamaz olmasidır(s. 167-202).

İzzetbegoviç eserinin ikinci kısmında ise İslam dinine değinir. İzzetbegoviç'e göre İslam'ın anlaşılması onun Yahudilik ve Hıristiyanlığı içine alan kısımlarının anlaşılmasından geçer. Zira İslam, bu iki din arasında bir denge unsurudur. Dolayısıyla burada söz konusu üç dinin birbirleriyle ilişkileri ve karşılaştırılmasını yapmaya çalışır. Ona göre Yahudilik, kendinde ölümsüzlük 
fikrini barındıran bir din olarak algılanır ve bu dinde Tanrının melekûtu ahirette değil dünyada beklenir; Dolayısıyla yazar, Yahudiliğin dünyevi bir özellik arz ettiğini, Hristiyanlığın da tam tersi manevi bir ilerlemeye sahip olduğunu söyler. İslam ise maddi ve manevi dünyayı kendinde birleştiren bir dini temsil eder. 'Dinin dünya üzerinde tesir icra etmesi ancak kendisi de dünyevi yani en geniş manada siyasi olursa mümkün olur. İslam yönünü dünyaya çevirmiş bir dindir." (s.256). Ayrıca Izzetbegoviç, İslam'1 anlamının bir diğer yolunun da onda var olan düalizmin manasını kavrayabilmek olduğu dile getirir. Ona göre, İslam'ın sahip olduğu bu ikili yap1 namaz, zekât, hac ve oruç gibi dini merasimlerle zuhur eder. Çünkü İslam'daki düalizm ibadetlerde kendini açıkça gösterir. Bir ibadeti yerine getirebilmek onun kendi iç şartlarına bağlı olduğu kadar dış şartlarına da bağlıdır. Namaz saatlerinin ayarlanması için astronomiye ihtiyaç duyulması, orucun manevi yönden öte, tıbbi açıdan da faydalarının olması ya da haccın dini bir ibadet olmasının yanında bir toplant1, ticaret ve fuar yerini de ifade ediyor olması düalizmin örnekleridir. Buradan hareketle İzzetbegoviç, İslam'ın bir düşünce tarzı olmanın daha üstünde bir yaşam tarzı olduğunu israrla savunur (s. 265-277).

Kitabın sonunda yazar, teslimiyet konusundan bahseder. Ona göre kaderin kabulü İslam'ın en büyük ve en son çağrısıdır. Kadere teslimiyet, insana hayatı olduğu gibi idrak edebilmeyi, sabrı ve tahammül etmeyi öğretir. İzzetbegoviç, insanın yaratıcısından kendisine gelen her şeye rıza göstermesini yani teslimiyeti, İslam'la eşdeğer görür ve şu sözleriyle eserini noktalar: ' $E \boldsymbol{y}$ teslimiyet! Senin adın İslam'dır' (s. 357-361).

Netice itibariyle Aliya İzzetbegoviçin bu eseri, modern dünyanın Müslüman bireylerinin, içinde bulunduğu zihni karmaşıklığı gidermek, İslam'ın Doğu medeniyeti ve Batı düşüncesi arasındaki yerini tespit edebilmek ve "Bilge Kral" olarak anılan, eserleriyle İslam dünyasına yeni bir soluk getiren İzzetbegoviç'in entelektüel bakış açısını anlayabilmek adına okunabilecek ve bu alanla ilgili araştırma yapılabilecek nitelikli bir eser olarak değerlendirmek mümkündür. 